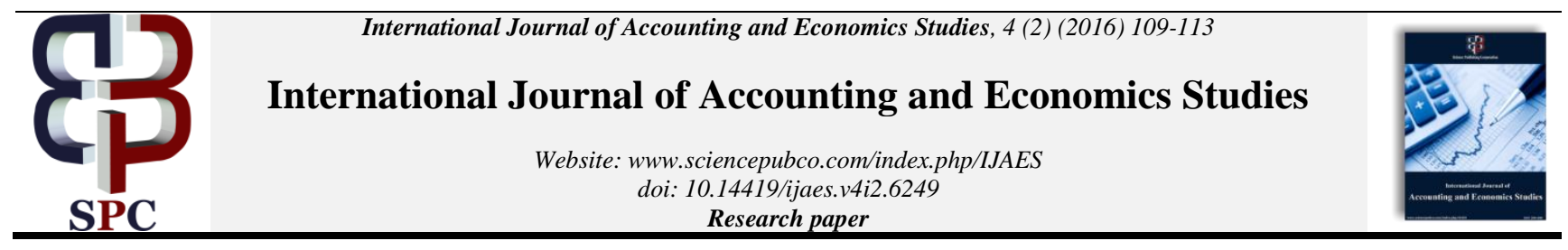

\title{
The effects of tax structure on economic growth: evidence from Pakistan economies
}

\author{
Mahfooz Khan Durrani ${ }^{1,2} *$, Saif ul Amin ${ }^{2}$, Samandar Khan ${ }^{3}$ \\ ${ }^{1}$ Department of IDS, University of Agriculture, Peshawar-Pakistan \\ ${ }^{2}$ Institute of Social Policy \& Research, Affiliated with Bacha Khan University, Charsadda-Pakistan \\ ${ }^{3}$ COMSATS Institute of Information Technology, Islamabad-Pakistan \\ *Corresponding author E-mail: msmahfoozkhan@yahoo.com
}

\begin{abstract}
The study has been conducted to find out the effects of fiscal policy on economic growth in Pakistan. Taxes are selected as a proxy for fiscal policy and GDP as an economic growth. In this study the time series analysis was used. The study used difference tests and models. These tests were unit root test which at different levels was used for stationary and non-stationary another model was cointegration the co-integration further used two tests one was trace test and second one was maximum Eigen value these tests used for long run relationships between taxes and GDP. In this study Granger causality test lag 2 and lag 4 also for checking the effects of taxes on Pakistan GDP. The objectives of the study are to find out the relationship between taxes and GDP and also to testify the random walk between taxes and GDP. The data were taken from 1981 to 2012. Taxes dealt as an independent and GDP as a dependent variable of the study. Data were collected from Federal Bureau of Statistics and from Pakistan economic survey. Time series analysis is used to testify the hypotheses. The results of Unit Root test shows that GDP and taxes has a unit root and it is non- stationary. GDP has no unit root and stationary in nature at 1st difference level. The results of co-integration shows that both taxes and GDP no co-integration at $5 \%$ level of significance. The study concludes that there is no Co-integration between taxes and GDP. The study recommended that fiscal policy should make according to the situation of the country and the tax rate should be change with a smooth rate.
\end{abstract}

Keywords: Taxes; Fiscal Policy; GDP; Economic Growth; Pakistan

\section{Introduction}

Taxes play an important role in the social and economic development with the help of implementation of policies that ensure equilibrium between expenditure, taxes and borrowing, which creates stable growth in the economy. The level of this relationship between taxes and Gross Domestic Product still attract the researchers for the research purpose and for the debate purpose in the developing countries (Amanja, 2005). The previous literature identifies two main aspects of the role of taxes in relationship with economic growth (Gross Domestic Product). One aspect is that the government supports the researcher to add something in the previous research work, handful investment, $\mathrm{R}$ and $\mathrm{D}$, to keep law and order and the supply of goods and services to general public. It can create expansion in the economic system both in short and long run (Riberoand Easterly 1993, Mauro 1995, Henrekson and Folster 1999). Secondly, the governments are non-apparent political system and also less efficient. The government in this case have try to control the growth rather to support it, but if they in volved in the production industry of the economic system. So the taxes are having effects on Gross Domestic Product and having inappropriate expenditure of government. The government always tries to upgrade their tax system by enhancing their fiscal policy. This policy refers to effects of government's fiscal policy in the economy due to Taxes and government expenditures. Best tax system plays an important role in the economic growth of Pakistan and other developing countries. For this reason, taxes are considered as the important factor for the economic growth (Gross Domestic Product). The effects of tax in the improvement of economic system in long run are the contentious issue and it needs more researches and explanation. In the beginning, lowering the tax with reducing in the expenditures will leads to increase the consumption and government expenditures and increase in interest earnings by increase in the individual income. Defiantly, as per the results of Richardian Equivalence Theorem, the above stated change in the Taxes will not direct to the mentioned effects. Shortly, by reducing the tax in deficit finance system will not give any macroeconomic benefits to the economy. The effects of taxes on Pakistan economic growth (Gross Domestic Product) is still in the beginning stages. Mahood and Shabir (1992), Iqbal (1998) and Mahmood and Khilji (1997) stated that financial deficiency in the economic system is the important factor that effect Pakistan Gross Domestic Product. Haq (2003) investigated that financial deficit have no such effects on investment, Inflation and Economic growth (Gross Domestic Product). This effect can be presented by transmission mechanism; the effects of Gross Domestic Product can be studied by demand and supply sides. As per the results of Khalid et al, (2008) taxes are measured as a dynamic transmission mechanism; due to it have long policy gaps for various macro factors and so, it is clear that the taxes have different effect on the key macro variables. By getting the significance of good fiscal policy, this research study has examine the relationship between taxes and economic growth (Gross Domestic Product) for the 
period of 1981 to 2012 in the Pakistan's economy. The research study will investigate the importance of taxes in the Pakistan economic system. In this study we use different model, different variables and different econometric models, this research study will test the significance of these selected models. The study will also put forward some recommendations on the policy for the development of good tax system in Pakistan's economy. In this study we determined the association and effects of Taxes on the Pakistan economic growth (Gross Domestic Product). Gross Domestic Product refers to the money value of goods and services bent within one year in the country. The current research study has examine the effects of fiscal policy (taxes) on the economic growth (Gross Domestic Product) of Pakistan, in current situation the public debts are increasing at a speed in Pakistan and the economic system is affected due to financial disequilibrium, which makes doubts about the sustainability of the Pakistan economic system . In the beginning 70's due to the nationalization policy, it makes huge government expenditures. Since in the 90's, the chief source of financing for Pakistan was remittance and international aid. As per the results of Montiel and Haq (1994) absence of political harmony on the expansion of tax system excluded any growth in the revenues and economic system, and deficiency in the fiscal policy become high due to the political instability and administrative inability to increase the revenue.

\subsection{Problem statement}

From the last few years Pakistan is continuing a great decrease in its Gross Domestic Product. Through this study we have attempt to find out the issues that happens in Gross Domestic Product because of financial strategy. Tax presumes crucial part in the development of Pakistani's economy. There is a great deal of obligation of taxes in different sections, however, because of its uncalled for structuring the impacts it shows is negative. Taxation is the backbone of the Gross Domestic Product. In Pakistan, there is no taxation framework that is the reason that Pakistan's economy can't create economic growth. The impact of tax on Gross Domestic Product is most crucial study particularly in the case of Pakistani economy.

\subsection{Objectives of the study}

The study has conducted with the following objectives;

1) To determine the relationship between taxes and Gross Domestic Product of Pakistan.

2) To inspect the effects of taxes on Pakistan Gross Domestic Product.

\section{Review of the literature}

In this section a brief review of current literature on relationship between Taxes and Gross Domestic Product is processed, both in international as well as Pakistani context.

Babalola and Aminu (2011) evaluated the impact of economic approach on financial development for Nigeria utilizing the disaggregated methodology throughout 1977 and 2009. They utilized Engle-Granger co-mix methodology to examine the effect of profitable, non-gainful, distortionary income and capital consumption on budgetary development. The study demonstrated that gainful uses and financial development were absolutely and altogether copartnered in long run. It may absolutely and unimportantly connect in the short way. The distortionary income and budgetary development had totally linked. The research work supposed that administration ought to use all the more on training, health and economic administrations for stimulating financial development.McCracken (2006) also investigated financial arrangement development by means of topographical examination and by utilizing 2 models one of which disaggregated the economic variables. One of the most dangerous effects of exchange payment and salaries tax and a negative correlation between government size and expansion distinguish. (The study sample size and region) Ogbol et al (2007) in the regulation and deregulation of the Nigerian economy improvements over time to break down the difference in the conduct of a similar study was directed. Nigerian national regulatory information received from the bank when they are used. Financial strategies to achieve better development impact of regulation and deregulation became apparent during the period. In contrast with the arrangement period, Gross Domestic Product was $14 \%$ higher during the period of liberalization. Mix together levelheaded approach using a fitting setting goals and financial strategies to increase the country's economic base open economy, the development of reasonable progress has been proposed by the creators.Gemmellet al (2006) Used Board of the OECD countries and found that the information in the long run; distortionary Taxes and costs make sense, an aggressive and positive effect on the enlargement of the OECD countries have individually. The extensive term effects had standardized in the sum of the OECD countries, while in the short-term effects in all such nations were very pronounced. The effects were achieved in the long term of the allocation of 1-3 years basically. Short term, lasting impact and showed were noteworthy that the financial agreement were not withdrawn progressions. This is additionally supported by Kneller was the result (1999) the development of this type of investment is examined adversely affected evaluations by distorting government consumption and absolutely affected by consumption.

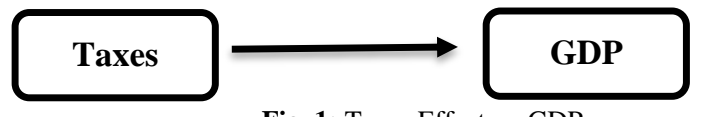

Fig. 1: Taxes Effect on GDP.

Source: Durrani, 2015

$\mathrm{H}_{1}$ : There is a positive relationship between taxes and Gross Domestic Product.

$\mathrm{H}_{2}$ : Taxes have an effect on Pakistan Gross Domestic Product.

\section{Research methodology}

\subsection{Universe of the study}

Table 1: Association between Taxes and Gross Domestic Product

\begin{tabular}{|c|c|c|c|}
\hline & & Taxes & GDP \\
\hline \multirow{3}{*}{ Taxes } & Pearson Correlation & 1 & $.995^{*}$ \\
\hline & Sig. (2-tailed) & & .000 \\
\hline & $\mathrm{N}$ & 32 & 32 \\
\hline \multirow{3}{*}{ GDP } & Pearson Correlation & $.995^{* *}$ & 1 \\
\hline & Sig. (2-tailed) & .000 & \\
\hline & $\mathrm{N}$ & 32 & 32 \\
\hline
\end{tabular}

**. Correlation is significant at the 0.01 level (2-tailed).Source:Secondary data

The study is based on historical time series secondary data of Government taxes (direct and indirect Taxes), and Gross Domestic Product of Pakistan's economy. The time series data is based on 65 years annual data of taxes and Gross Domestic Product (19472012).

\subsection{Sample size and sampling technique}

The sample size includes annual time series data for at least 22 years from fiscal year (FY) 1982 to fiscal year (FY) 2012.The study is based on secondary data.

\subsection{Variables of the study}

The impact of taxes on Pakistan's Gross Domestic Product has been analyzed by distinctive economists, utilized diverse sorts of variables. Every one of them have utilized distinctive models and discovered diverse effects. Because of the uncommon emphasis on the expenses and Gross Domestic Product, we utilized the accom- 
panying variables within our study. In this study the following variables has been used.

\subsubsection{Independent variable}

The study takes taxes as an independent variable. Taxes included the direct and indirect taxes. In the direct taxes, we take Income tax, Worker welfare tax, capital worth tax for the estimation of direct taxes and for indirect taxes, Custom and duty, Federal extract estimation and bargains duty is chosen for the study. The reason of selecting these sub sorts of expenses is accessibility of information with State Bank of Pakistan.

\subsubsection{Dependent variable}

The Gross Domestic Product taken as a dependent variable for research study. Gross Domestic Product represents economic growth. Gross Domestic Product means all final goods and services produced in a country during one year.

\subsection{Data collection}

The data has been taken and compile form this websites, The State Bank of Pakistan, Federal Bureau of Statistics, Ministry of finance of Pakistan and Business Recorder website (www.businessrecorder.com), Business magazines of Business Recorder, International Financial Statistics (IFS) and different issues of Pakistan economic survey.

\subsection{Data analysis}

To find out the effects of taxes on Pakistan Gross Domestic Product, the co-integration analysis technique is used. The variables i.e. Taxes (DITX) and Gross Domestic Product (GDP) are included in the study.

Table 2: ADF Test for Level Intercept

\begin{tabular}{lcc}
\multicolumn{3}{c}{ Table 2: ADF Test for Level Intercept } \\
\hline & $\mathrm{t}$-Statistic & Prob.* \\
\hline Augmented Dickey-Fuller test statistic & 1.304704 & 0.9981 \\
Test critical values: 1\% level & -3.661661 & \\
5\% level & -2.960411 & \\
10\% level & -2.619160 & \\
\hline Source: Secondary data &
\end{tabular}

\section{Data analysis and interpretation}

\subsection{Correlation}

Table 3: ADF Test for GDP (1st Diff-Trend and Intercept)

\begin{tabular}{lcc} 
& t-Statistic & Prob.* \\
\hline Augmented Dickey-Fuller test statistic & -5.670902 & 0.0003 \\
Test critical values: $1 \%$ level & -4.296729 & \\
$5 \%$ level & -3.568379 & \\
10\% level & -3.218382 & \\
\hline Source:Secondary data &
\end{tabular}

Correlation refers to the association between two or more than two variables. In this study we have two variables Gross Domestic Product and taxes. Correlation tests the association between Gross Domestic Product and taxes.

Table 4: Co-Integration Rank Test for Trace

\begin{tabular}{lllll}
\hline $\begin{array}{l}\text { Hypothesized No. } \\
\text { of CE(s) }\end{array}$ & $\begin{array}{l}\text { Eigen } \\
\text { value }\end{array}$ & $\begin{array}{l}\text { Trace } \\
\text { Statistic }\end{array}$ & $\begin{array}{l}0.05 \text { Critical } \\
\text { Value }\end{array}$ & \multirow{2}{*}{ Prob.** } \\
\hline None & 0.176259 & 7.259651 & 15.49471 & 0.5477 \\
At most 1 & 0.046952 & 1.442690 & 3.841466 & 0.2297 \\
\hline
\end{tabular}

Source:Secondary data

Table 5: Co-Integration Rank Test for Maximum Eigen Value

\begin{tabular}{lllll}
\hline $\begin{array}{l}\text { Hypothesized No. } \\
\text { of CE(s) }\end{array}$ & $\begin{array}{l}\text { Eigen } \\
\text { value }\end{array}$ & $\begin{array}{l}\text { Max-Eigen } \\
\text { Statistic }\end{array}$ & $\begin{array}{l}0.05 \text { Critical } \\
\text { Value }\end{array}$ & Prob.** \\
\hline None & 0.176259 & 5.816961 & 14.26460 & 0.6368 \\
At most 1 & 0.046952 & 1.442690 & 3.841466 & 0.2297 \\
\hline
\end{tabular}

Source: Secondary data
The table.1 shows the Pearson correlation results of taxes and Gross Domestic Product. The value of correlation from the table. 1 is 0.995 which means that the taxes have strong positive relationship with Gross Domestic Product at 5\% level of significance and this relationship is strongly positive. It means that with the increase in taxes, Gross Domestic Product has increase and this relationship is significant at $5 \%$ level of significance. The same results can be getting from the paper of Hakim (2012), the tax revenues have positive correlation with economic growth (GDP).

\subsection{Unit root test}

In macroeconomics the most of the variables are non-stationary in this manner the first step is to figure out that the applicable variables are stationary OR non-stationary and to focus their request of incorporation. We utilize the Augmented Dickey Fuller (ADF) test to find the existence of unit root in each of the time series. The results of both the ADF and PP tests are reported in the Table. 2.

\subsection{Augmented dickey fuller test for GDP (level- intercept)}

Augmented Dickey Fuller Test is the test of unit root test. It has test the stationary or non-stationary of the data. Augmented Dickey Fuller Test that Gross Domestic Product has unit root and Gross Domestic Product has not unit root.

The effect in the bench demonstrates that all the variables had not stationary in stage. It might be seen by evaluate the experimental principles are at $1 \%$ and in brackets $5 \%$ level of confidence interval. Result from the table. 2 provides strong evidence of nonstationary. Therefore, the null hypothesis is accepted and it is sufficient to conclude that there is a presence of unit root in the variables at levels. The same result can be obtained from the research work of Elder (2001). The results states that Gross Domestic Product has a unit and not stationary at levels. This means that variation in Gross Domestic Product is not constant.

\subsection{Augmented dickey fuller test for GDP (1st diff - trend and intercept)}

Augmented Dickey Fuller Test also test at $1^{\text {st }}$ different and trend it also test the data of Gross Domestic Product has unit root (nonstationary) and the data of Gross Domestic Product has not unit root (stationary).

The result in the table. 3 shows that the Gross Product Domestic variable is stationary in first difference and with trend and intercept. Result from the table. 3 provides strong evidence of stationary. Therefore, the alternate hypothesis is accepted because the $p$ value is less than $5 \%$ of level of significance and it is sufficient to conclude that there is an absence of unit root in the variables at levels. The same results can be getting from the research work of Papell and Prodan (2012). The results states that Gross Domestic Product has no unit and the data is highly stationary.

\subsection{Co-integration rank test}

Table 6: Pair Wise Granger Causality Test for Lag-2

\begin{tabular}{llll}
\hline Null Hypothesis: & Obs & F-Statistic & Prob. \\
\hline Taxes does not Granger Cause GDP & 30 & 2.49930 & 0.1024 \\
GDP does not Granger Cause Taxes & & 6.99009 & 0.0039 \\
\hline
\end{tabular}
Source: Secondary data

Co-integration test used for after the unit root test. In this study Co-integration shows the linear long run relationship between Gross Domestic Product and taxes. Co-integration rank test is used to check the data of Gross Domestic Product and taxes has stationary for long run or to test the data of Gross Domestic Product and Taxes has non-stationary for long run. If there is Cointegration between Gross Domestic Product and taxes then there is a long run equilibrium relationship between Gross Domestic Product and taxes Series. GDP Taxes 
Lags interval (in first differences): 1 to 1 Unrestricted Cointegration Rank Test (Trace).

Table 7: Pair Wise Granger Causality Test for Lag-4

\begin{tabular}{llll}
\hline Null Hypothesis: & Obs & F-Statistic & Prob. \\
\hline Taxes does not Granger Cause GDP & 28 & 1.53883 & 0.2312 \\
GDP does not Granger Cause Taxes & & 2.20685 & 0.1070 \\
\hline Source: Secondary data & & &
\end{tabular}

To have established the immobile of the variables, they continue to inspect the attendance or non-presence of co-integration amongst the variables. When a co-integration association is there, it means that GDP and taxes have long relationships. The cointegration model examine by utilize the Johansen test. The results of the table. 4 shows trace test that the $p$ value of trace test which is highly insignificant at 5\% level of significance and we conclude that there is no co-integration between GDP and taxes according to trace test. The results can be getting from the research of Guisan and Carmen (2001). The GDP has no co-integration by per the results of trace test.

Unrestricted Co-integration Rank Test (Maximum Eigen value). We started the co-integration analysis by employing the Johansen test. The results of the table.5 shows maximum Eigen value that the $\mathrm{p}$ value is greater than the $5 \%$ level of maximum Eigen value which is highly insignificant under 5\% level of significance and we conclude that there is also no co-integration between taxes and GDP variables according to maximum Eigen value test. The results can be getting from the research of Guisan and Carmen (2001). There is no co-integration between Gross Domestic Product and taxes according to the results of maximum Eigen test.

\subsection{Pair wise granger causality tests}

When co-integration between taxes and Gross Domestic Product is exists then we used error correction model. But in this study there is no co-integration between taxes and Gross Domestic Product therefore we used pair wise granger causality test. Pair wise Granger Causality Test check taxes causes GDP and GDP cause taxes according to different lags. In this study we used 2 lags and 4 lags. Sample: 1982- 2012 Lags: 2.

The table. 6 shows that G represents GDP and $\mathrm{T}$ represents taxes. Granger causality test results suggest that the null hypothesis that taxes does not Granger cause GDP is accepted, which indicates that causality runs from GDP to taxes. The other null hypothesis is that GDP does not Granger cause taxes and the $p$ value of this is less than $5 \%$ which shows the acceptance of alternate hypothesis and conclude that causality runs from GDP to taxes. The same results can be seen in the research of Mashkoor, Yahya and Ali. (2010).

Sample: 1984-2012Lags: 4.

The table. 7 shows that the result of 4 lags. Granger-causality test results suggest that the null hypotheses that taxes do not Granger cause GDP is accepted, which indicates that causality test runs from GDP to taxes. The other null hypothesis is that GDP does not Granger cause taxes and the $p$ value of this is higher than 5\% level which shows the acceptance of null hypothesis and concludes that in lag 4 both the null hypotheses taxes does not Granger cause GDP and GDP does not Granger cause taxes has accepted and causality runs from GDP to taxes. The same results can be seen in the research of Mashkoor, Yahya and Ali. (2010).

\section{Conclusion}

The study was conducted to find out the effects of fiscal policy on Pakistan Economic growth. Taxes have been selected as a proxy of fiscal policy and Gross Domestic Product as economic growth Taxes are the independent and Gross Domestic Product as dependent variable. The data from 1947 to 2012 was selected as universe and from 1981 to 2012 as a sample of the study.

Time series analysis was used in the data analysis. In time series analysis includes unit root test for checking stationary and non- stationary, co-integration model which are used for long run relationships, Granger causality test. The study concludes that both taxes and Gross Domestic Product has no unit root evidence from the augmented dickey fuller test results show in their respective tables. The test has been run at levels. While at first difference the augmented dickey fuller test (ADF) results shows that Gross Domestic Product has unit root and the data is stationary. Two test regarding the checking of co-integration i.e. trace test and maximum Eigen value test was used and the results from both tests suggests that is no co-integration between taxes and Gross Domestic Product. The Granger causality test was run in two lags i.e. 2 lags and 4 lags. The results of 2 lags shows that taxes does not Granger cause Gross Domestic Product and causality flows from Gross Domestic Product to taxes while the results of 4 lags shows that taxes does not Granger cause Gross Domestic Product and same is the case with Gross Domestic Product to taxes.

\section{Recommendation}

The result of correlation shows that the taxes and Gross Domestic Product has strong positive relationship. So this study recommended that the tax rate should increases but a constant rate. The taxes affect Gross Domestic Product 98\% if 1\% increases in taxation, then 1.016 has increases in Gross Domestic Product from this study we find out that taxes has a lots of contribution in Gross Domestic Product of Pakistan.

So the Government should totally focus on Fiscal Policy and the Fiscal Policy should make according to the economic situation of Pakistan and it should be properly implementing.

So the unit root test result shows that the data of Gross Domestic Product and taxes are not stationary, it should be stationary. The study recommended that the Government should not change the tax rate again and again.

\section{References}

[1] Amanja, D. M., and Morrissey, O. (2005), "Fiscal Policy and Economic Growth in Kenya", Credit Research Paper, 05/06, pp.1-35.

[2] Babalola, S.J. and U. Aminu, 2011.Fiscal policy and economic growth relationship in Nigeria.Inter. J. of Busi.and Soc. Sci, 2(17).

[3] Barro, R. J. (1974). Are Government Bonds Net Wealth? J. of Poli. Econ, 82, 1095-1117. http://dx.doi.org/10.1086/260266.

[4] Barro, R. J. (1979). On the Determination of the Public Debt.J.ofPoli. Econ, 87(5), 940-971. http://dx.doi.org/10.1086/260807.

[5] Devarajan, Shantayanan, S. Vinaya and Heng-fuZou., 1996.The composition of public expenditure and economic growth.J.of Mon. Econ, 37.

[6] Devereux, M. B., and Love, D. R. (1995).The Dynamic Effects of Government Spending Policiesin a Two-Sector Endogenous Growth Model.J. of Mon., Crd and Ban, 27(1), 232-256. http://dx.doi.org/10.2307/2077861.

[7] Gemmell, N., Kneller, R., andSanz, I. (2006). Fiscal Policy Impacts on Growth in the OECD: Are They Long- or Short-Run?

[8] Ghosh, S. and A. Gergoriou, 2006.On the composition of government spending optimal fiscal policy and endogenous growth. Theory and Evidence, Brunel University Discussion Paper No. 06-19.

[9] Gupta, S., B. Clements, E. Baldacci and C. Mulas-Granados 2005. Fiscal policy, expenditure composition and growth in lowincome countries. Journal of International Money and Finance, 24 http://dx.doi.org/10.1016/j.jimonfin.2005.01.004.

[10] Karras, G. (1999). Taxes and Growth Testing the Neoclassical and Endogenous Growth Models.Cont.Econ.Poli., 17 (3), 177-188. http://dx.doi.org/10.1111/j.1465-7287.1999.tb00673.x.

[11] Kim, S.-J. (1992). Taxes, Growth and Welfare in an Endogenous Growth Model.Ph.D.dissertation.

[12] Kneller, R., M.F. Bleaney and N. Gemmell, 1999. Fiscal policy and growth: Evidence from OECD countries. Journal of Public Economics, 74. http://dx.doi.org/10.1016/s0047-2727(99)00022-5.

[13] McCallum, B. T. (1996). Neoclassical vs. Endogenous Growth Analysis: An Overview. FRBRichmond Economic Quarterly, 82 (4).

[14] Mccracken, C. (2006). Whether Fiscal Policy State Affects State Economic Growth. 
[15] Romer, C. D., andRomer, D. H. (2007). The Macroeconomic Effects of Tax Changes: Estimates Based On a New Measure of Fiscal Shocks.

[16] Romer, P. M. (1986).Increasing Returns and Long-Run Growth.The J. of Poli. Econ., $94 \quad$ (5), $1002-1037$ http://dx.doi.org/10.1086/261420.

[17] Romer, P. M. (1990).Endogenous Technological Change.The J. of Poli.Econ, 98(5), S71-S102. http://dx.doi.org/10.1086/261725. 